\title{
Drafting of research instruments to study the development of television news brand identity
}

\author{
Praweenamai Baicloy $^{1}$, , Jantima KHEOKAO ${ }^{2,}$ \\ D.Com.Arts in Marketing Communication (Candidate), Faculty of Communication Arts, \\ UTCC, THAILAND \\ Associate Professor, Faculty of Communication Arts, UTCC, Thailand *Corresponding author
}

\begin{abstract}
.
Brand identity of Thai television news programs has not attracted attention from researches despite it is as the soul of media brand. In the digital television era, a strong brand identity is an important factor in its success. It helps the audience differentiate the news program brand from competitors, make the brand stand out and directly impact to profitability. To study the development of Thai television news brand identity, the starting point is to draft the research instruments. This article aims to collect and synthesize research instruments for the study of the development of television news brand identity. This study is a qualitative research that provides a systematic review of existing researches. Sixteen articles in Google Scholar and EBSCOhost database in 2000-2018 were found relating to television news brand identity. Two articles are Thai researches, while other fourteen articles are international researches. Twelve papers (from sixteen papers) used the quantitative method, two papers used qualitative method and two papers applied mixed-method. Among the papers using quantitative method, the survey with questionnaires as research instrument is applied most. There are five researches directly focusing on "Brand Personality". The other elements of "Brand Identity" (Brand vision, Brand culture, Brand positioning, Brand Relationship and Brand Presentation) are not stated explicitly in the reviewed papers. In order to fulfil a brand identity model for TV news program, further study in the other TV brand identity elements shall be conducted.
\end{abstract}

Keywords: Brand identity; Media branding; News program branding; Television news 


\section{Introduction}

\subsection{History of TV News Programs in Thailand}

Throughout seven decades of the history of the Thai television broadcasting industry, from the launch of the Thai TV Channel 4, or Channel 4 Bang Khun Prom in 1955 till now, it is apparent that news programs are the utmost important to all television channels. This is in line with the Royal Gazette's regulations governing the television program which require TV operators provide a public access to useful contents or information to the general public

The National Broadcasting and Telecommunications (NBTC) estimated that each news program attracted between 100,000 and 2,000,000 viewers in 2019.

Amid the fierce competition in the television news broadcasting industry, TV news program operators have adopted the concept of brand identity as a key strategy to make themselves stand out from others in order to attract targeted viewers for each news program (Chan-Olmsted and Cha, 2008).

Besides, the self-perpetuation strategy enables a news program to continue to exist amid the challenges of staying competitive is apparent (Von Rimscha, 2015). The case in point here is a television news program ran by veteran journalist Dr. Somkiat Onwimon and his news production team in 1986. Dr. Somkiat Onwimon and his crews sub-divided the news program presentation into different time slots. They also replaced the ordinary broadcasting method by a TV news anchor with live broadcasting technique.

In 1995, Independent Television (iTV) was born with the image of being an "independent television station". The station has the goal of becoming Thailand's first television station by featuring the news's coverage of the investigation, in-depth news analysis, special reports and the investigations into any possible irregularities.

In 2004, Channel 3 reformatted its news programs bulletins by making its news contents easier for viewers to digest. Afterwards, the station launched a news program called "Channel 3 family news" with the slogan, "understand every news, greater access to everyone".

In 2016, remarkable changes in the Thai television broadcasting industry with greater choices from new TV operators have forced television news operators to improve the contents of their news programs and the presentation methods to better communicate with viewers. They tried to win over the audience by establishing brand identity and attract them with recognizable logos, channel numbers to create brand loyalty. Among the severe competition, TV digital TV channels from total 22 digital TV channels returned their licence to NBTC in 2019 and the revenue of operating channels has been decreasing. To promote TV news program brand, the research on brand identity is necessary.

\subsection{Status of Research on Media Brand Identity}

After reviewing several researches on the concept of brand management for news television programs over the past 10 years, it is found that both Thai and foreign researchers have presented various interesting points of views which can be applied in the further research.

To name a few, key success factors of TV brand management was identified by analysing ten different TV brands in the U.S., the U.K., Spain, and Germany (Förster, 2015, Sjovaag, 
2012). The building of television brands was studied in the digital multi-channel world (Singh, 2004).

The concept of "brand image and brand personality" of television channels and their programs are vital to television operators' brand management to fully maximize their brands' potential (Mcdowell and Batten, 2005).

Sylvia Chan-Olmsted (Chan-Olmsted \& Cha, 2007) and Kim (Kim, 2018) conducted an exploratory study of network news brand personality and also a study on consumers' loyalty and brand relationships (Chan-Olmsted and Cha, 2008). Jittanggoon and Anantachart researched on brand personality in Thai news programs (Jittanggoon \& Anantachart, 2010). Mcdowell and Batten studied on how the principles of brand management can be used to attract new viewers, promote audience and halt increasing media competition (Mcdowell \& Batten, 2005).

Despite a large number of researches on the brand management of television news, most studies mainly focused on brand building strategy and brand personality but lack of the concept of brand identity. In fact, brand identity is a key element of brand development since it determines branding objectives, goals and the value of a product. It is an important way for one to distinguish products among others. Brand identity, according to Aaker (1996), represents how the brand wants to be perceived, it leads brand image and is situated on the sender's side. Besides, brand identity helps consumer to recall and recognize the brand recognize the brand under different conditions (Kapferer, 2012).

As the first step, this study is to systematic review of research instruments and variables to be applied.

\subsection{Research Purpose}

The author aims to study the history of brand identity of Thai television news programs since 1955 when the first television channel was launched for the assessment on future trend of news programs and to develop the brand of television news programs.

\section{Literature Review}

\subsection{Concept of Brand Identity}

A number of studies on the concept of "brand identity" share similar notions of brand identity. Kapferer (2012) argued that having an identity indicates "being true self driven by a personal goal that is different from others' and resistant to change". A brand identity needs to resonate with customers, differentiate the brand from competitors, and represent what the organization can and will do over time (Aaker and Joachimsthaler, 2000).

The brand identity comprises of two elements; specialization and authority (Kitchen \& Schultz, 2003). Konecnik and Go provided insights into the concept of brand identity which is that brand identity is what the brand inspires to be (Konecnik and Go, 2008). The brand of a product or service needs to have its own unique identity that set it apart from the rest in the crowd and be recognizable by its customers.

To conclude here, the notion of brand identity is a unique identity of a product in which a 


\section{SOCIAL SCIENCES IN THE 21ST CENTURY}

brand strategist seeks to create and maintain in order to deliver a promise of what will be delivered or fulfilled. From the definitions of brand identity mentioned above, it can be concluded that having a brand identity is being your true self, with an authentic identity. Brand identities not only reflect the core identity that is resistant to change but are also built using two elements; specialization and authority.

A number of media scholars have studied the concept of brand identity (Kapferer, 1986; Upshaw, 1995; Aaker, 1996; De Chernatony, 1999). Those frameworks have been referenced in the academic literature (De Chernatony, 1999; Azoulay and Kapferer, 2003). Besides, the description of brand identity has been adopted and extended to the corporate world. According to Harris and De Chernatony, corporate brand identity in business management consists of six components: vision, culture, positioning, personality, relationship and presentation (Harris and De Chernatony, 2001). It is shown that De Chernatony's brand identity model has been applied in various fields; therefore, the author considers that De Chernatony's brand identity model (Figure 1) can be applied to the brand identity study of TV news program.

Figure 1 De Chernatony's Brand Identity Model (De Chernatony, 1999)

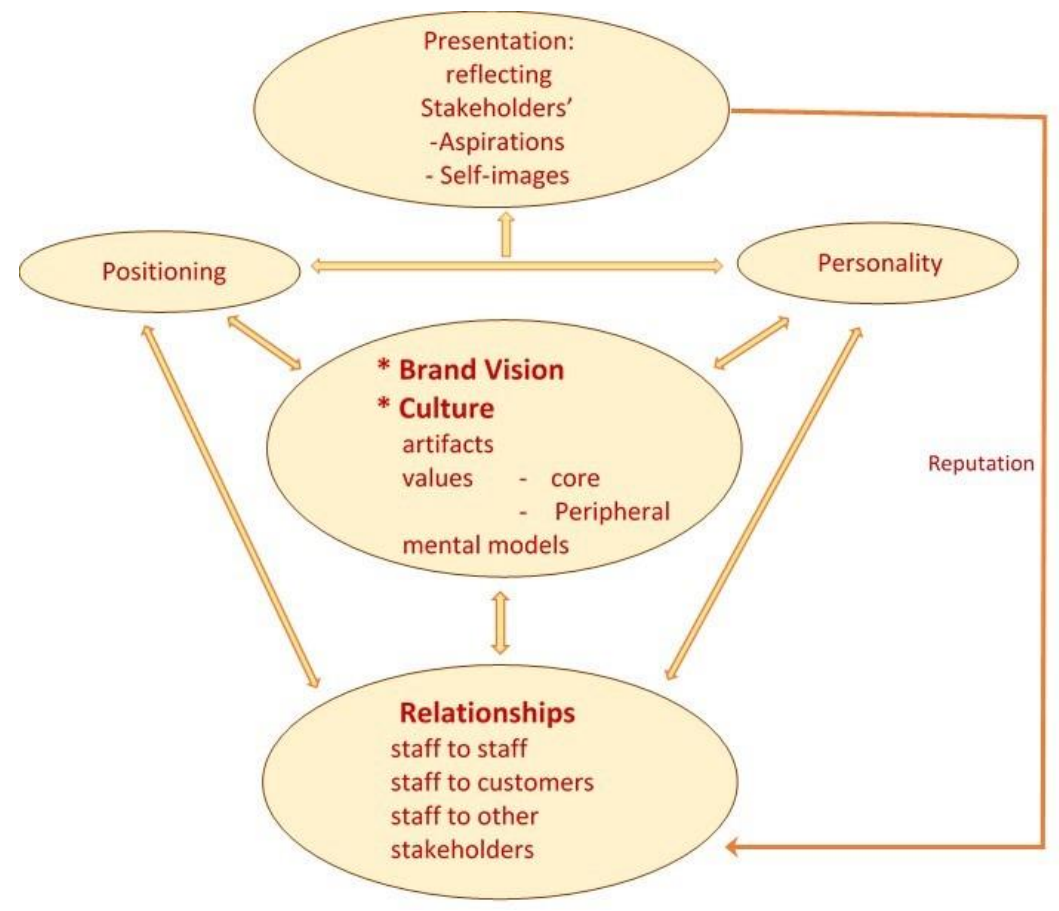

\subsection{The concept of news and news value}

Michael Schudson, a researcher of journalism history in the US, stated that the term "news" was mentioned for the first-time during Andrew Jackson's presidency in 1830s. He described the way the Penny press treated news stories as up-to-date, accurate and complete information. Then, in 1848, the Associated Press (AP) described "news" as "true facts" (Palczewski, 2009). The definition of news was put forward in three different ways:

(1) News values in terms of how news conveys a live event, an interesting event, a surprising event, or an astonishing event. In terms of news dimensions, the issue of news values 
was studied by observing Danish TV journalists (Schultz, 2007). Schultz argued that six news values dominate: timeliness, relevance, identification, conflict, sensation and exclusivity. Harcup and O'Neill identified 15 news values from a selection 711 pages lead articles from 10 British newspapers which include exclusivity, bad news, conflict, surprise, audio-visuals, share ability, entertainment, drama, follow-up, power elite, relevance, magnitude, celebrity, good news and news organization's agenda (Harcup and O’Neill, 2017).

(2) The subject of journalism was described as a product of news organization. Tuchman argued that news does not reflect reality as it is being constructed as a social phenomenon (Tuchman, 1978). It is the activity of media organizations employees; they decide which event possesses news value. Tuchman uses the news category as a "frame". He defined the "frame" as rules of organization that control public events. According to Tuchman's definition of the "frame", news as something which politicians' agenda or what they want to say or something which news organization's agenda or what the audience consumes at the time.

(3) The concept of news believed in the functional approach that news is made or manufactured (Roshco, 1975).

In conclusion, the concept of news can be defined as a report of an event or even an opinion of a reporter and an editor on an event in which they have selected with confidence to attract viewers' interest.

\subsection{The concept of television news}

Television news is different from other types of news media due to the nature of its news composition (Cushion, 2012). The concept of television news was defined in different ways by scholars.

Noppakhun defined television news as the presentation of a series of an individual event with audio description and pictures. Good television news can be recognized not only by a good content but also by pictures and voices that feature in the news (Noppakhun, 1998).

Woraphan defined television news as information that is gathered from the real event (Woraphan, 1982). It is news and interesting and may have some impact on the general public and as so, television reporters are allowed to convey, report, take pictures of and record the event in order to broadcast it to feature in domestic news or foreign news section or sports news section. They may analyse the event and pass it on to the public through pictures, motion pictures or TV presentation.

A television news program is a program that is created or produced to depict a series of individual stories by reporters. It can be live or recorded interviews by field reporters with or without pictures. The production of a television news program involves the searching, collecting, processing and compiling of data. Reporters analyse and then write news scripts for the event in a concise and clear manner before forwarding them to a news presenter or an news anchors within a suitable timeframe (Hongprayoon, 2007).

Analysing the above definitions of television news, it can be concluded that television news program is a program that presents a description of an event and is transmitted through the medium of the television. It involves the process of finding, compiling and reporting through the form of pictures and audio description. 


\section{SOCIAL SCIENCES IN THE 21ST CENTURY}

The literature review results on news value and TV news program production shows that all elements of De Chernatony's brand identity model (Brand vision/culture, brand positioning, brand personality, brand relationship, and brand presentation) are necessary for brand identity of TV news program. Therefore, the author proposes the conceptual model for TV news program brand identity by adopting De Chernatony's brand identity model as indicated in Figure 2.

Figure 2 De Chernatony's Brand Identity Model modified for TV News Program

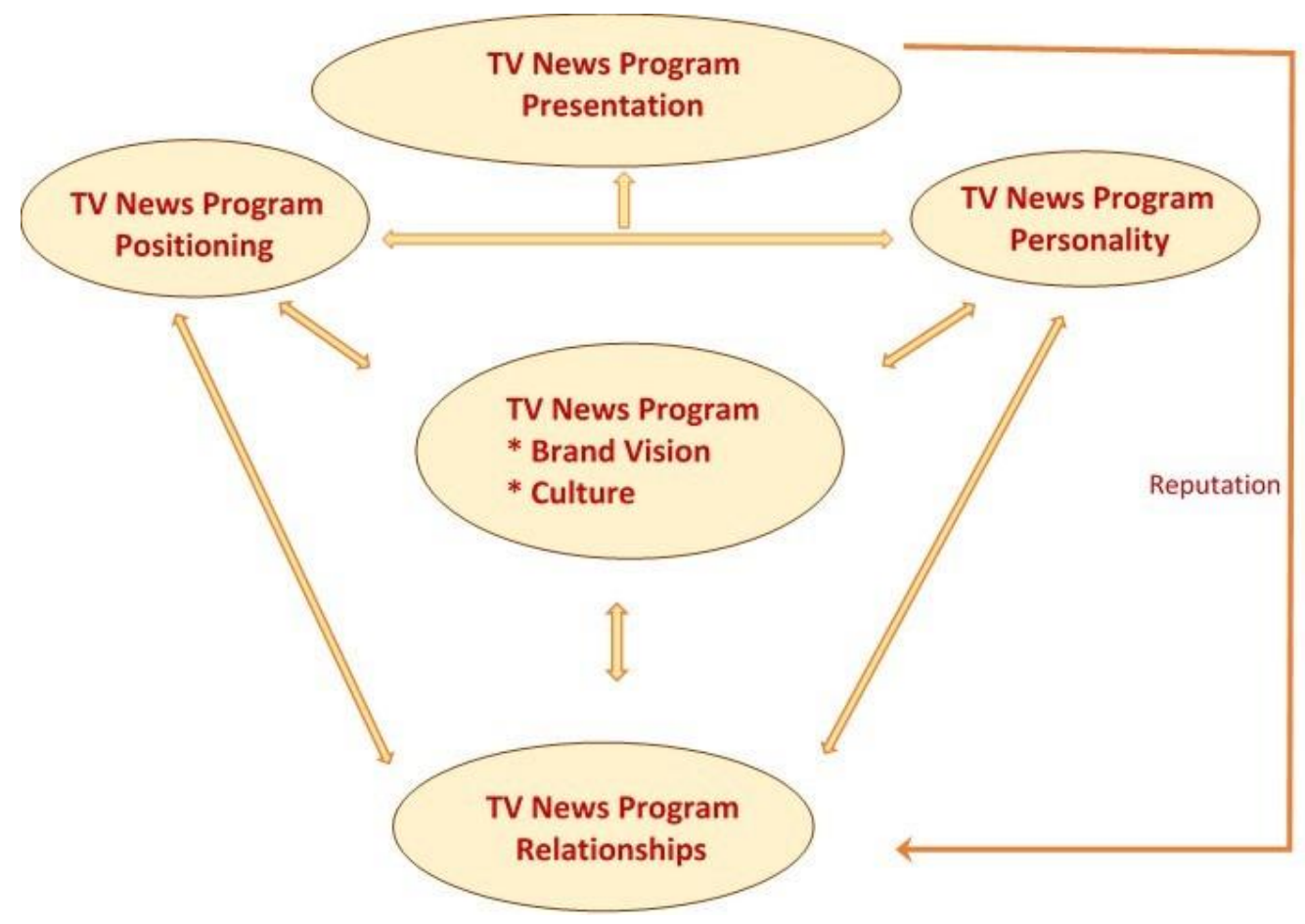

\section{Research Methodology}

The method of systematic reviewing have been developed to apply for this study. The author sought to identify studied that reported the development of instruments that aimed to evaluate television news brand identity. The following database: Google Scholar (2000-2018) and EBSCOhost (2000-2018) are used for searching with keyword terms relating to media branding, television news branding. From the search result, sixteen papers published during 2000 to 2018 were found.

\section{Results and Discussion}

Sixteen papers as listed in Table 1 are found and used in this research study. It is found that the methodology of those researches are quantitative, qualitative and mixed methods. In the quantitative method, survey, content analysis and documentary are introduced. While, for the qualitative method, in-depth interview is applied. 
Twelve papers (from sixteen papers) used the quantitative method, two papers used qualitative method and two papers applied mixed-method. Among the papers using quantitative method, the survey with questionnaires as research instrument is applied most (seven papers). The second frequent-use quantitative method is the content analysis with coding form as research instruments.

"Brand Personality" is the most frequent use topic among the sample papers (five papers). There are also several papers discussed about "Promotion strategy" and "Product Differentiation". However, other elements shown in De Chernatony's brand identity model has not been referred to in those papers (as indicated in Figure 3). It is necessary to study in the other elements to accomplish the model of "Brand Identity" for TV news program.

Table 1 Systematic Review of Methodology and Research Instruments

\begin{tabular}{|c|c|c|c|c|}
\hline No & Authors (Year) & Methodology & Research Instruments & Area of Interest \\
\hline 1 & $\begin{array}{l}\text { Chan-Olmsted \& Cha, } \\
2007\end{array}$ & \multirow{7}{*}{$\begin{array}{l}\text { Quantitative } \\
\text { (Survey) }\end{array}$} & \multirow{7}{*}{ Questionnaires } & News Brand Personality \\
\hline 2 & $\begin{array}{l}\text { Chan-Olmsted \& Cha, } \\
2008\end{array}$ & & & News Brand Personality \\
\hline 3 & $\begin{array}{l}\text { Jittanggoon \& } \\
\text { Anantachart, } 2010\end{array}$ & & & Brand Personality \\
\hline 4 & Santin \& Rubira, 2014 & & & $\begin{array}{l}\text { Promotional Strategies in } \\
\text { News Program }\end{array}$ \\
\hline 5 & $\begin{array}{l}\text { Kumar \& } \\
\text { Venkatesakumar, } 2015\end{array}$ & & & Brand Personality \\
\hline 6 & $\begin{array}{l}\text { Cheng \& Mitomo, } \\
2017\end{array}$ & & & $\begin{array}{l}\text { Perceived Image of TV } \\
\text { News }\end{array}$ \\
\hline 7 & Kim, 2018 & & & $\begin{array}{l}\text { News Media Brand } \\
\text { Personality }\end{array}$ \\
\hline 8 & Bae, 2000 & \multirow{4}{*}{$\begin{array}{c}\text { Quantitative } \\
\text { (Content Analysis) }\end{array}$} & \multirow{4}{*}{ Coding Form } & $\begin{array}{l}\text { Product Differentiation of } \\
\text { TV Newscast }\end{array}$ \\
\hline 9 & $\begin{array}{l}\text { Gutierrez San Miguel } \\
\text { et al., } 2010\end{array}$ & & & $\begin{array}{l}\text { Production of News } \\
\text { Program }\end{array}$ \\
\hline 10 & $\begin{array}{l}\text { Daniels \& Loggins, } \\
2010\end{array}$ & & & Product Differentiation \\
\hline 11 & Coffey \& Cleary, 2011 & & & $\begin{array}{l}\text { Promotion and Branding of } \\
\text { Cable News Network }\end{array}$ \\
\hline 12 & Siegert et al., 2011 & $\begin{array}{c}\text { Quantitative } \\
\text { (Documentary) }\end{array}$ & Recording Form & $\begin{array}{l}\text { MBAC Model } \\
\text { (Media, Brands, Actors, } \\
\text { Communication) }\end{array}$ \\
\hline 13 & Singh, 2004 & \multirow{2}{*}{$\begin{array}{c}\text { Qualitative } \\
\text { (In-depth Interview) }\end{array}$} & \multirow{2}{*}{ Interviewing Form } & Building TV Program Brand \\
\hline 14 & $\begin{array}{l}\text { Shaw \& Moungkaew, } \\
2016\end{array}$ & & & $\begin{array}{l}\text { TV News Program Brand } \\
\text { Identity }\end{array}$ \\
\hline 15 & Sjovaag, 2012 & $\begin{array}{c}\text { Mixed-method } \\
\text { (In-depth Interview and } \\
\text { Content Analysis) }\end{array}$ & $\begin{array}{l}\text { Interviewing Form } \\
\text { (Coding Form) }\end{array}$ & $\begin{array}{l}\text { Self-presentation of TV } \\
\text { Brand Strategy }\end{array}$ \\
\hline
\end{tabular}




\begin{tabular}{|c|l|c|c|l|}
\hline 16 & Forster, 2011 & $\begin{array}{c}\text { Mixed-method } \\
\text { (Documentary and Content } \\
\text { Analysis) }\end{array}$ & $\begin{array}{c}\text { Recording Form } \\
\text { Coding Form }\end{array}$ & $\begin{array}{l}\text { TV Branding } \\
\text { (Brand Promise, Brand } \\
\text { Positioning, Brand } \\
\text { Architecture) }\end{array}$ \\
\hline
\end{tabular}

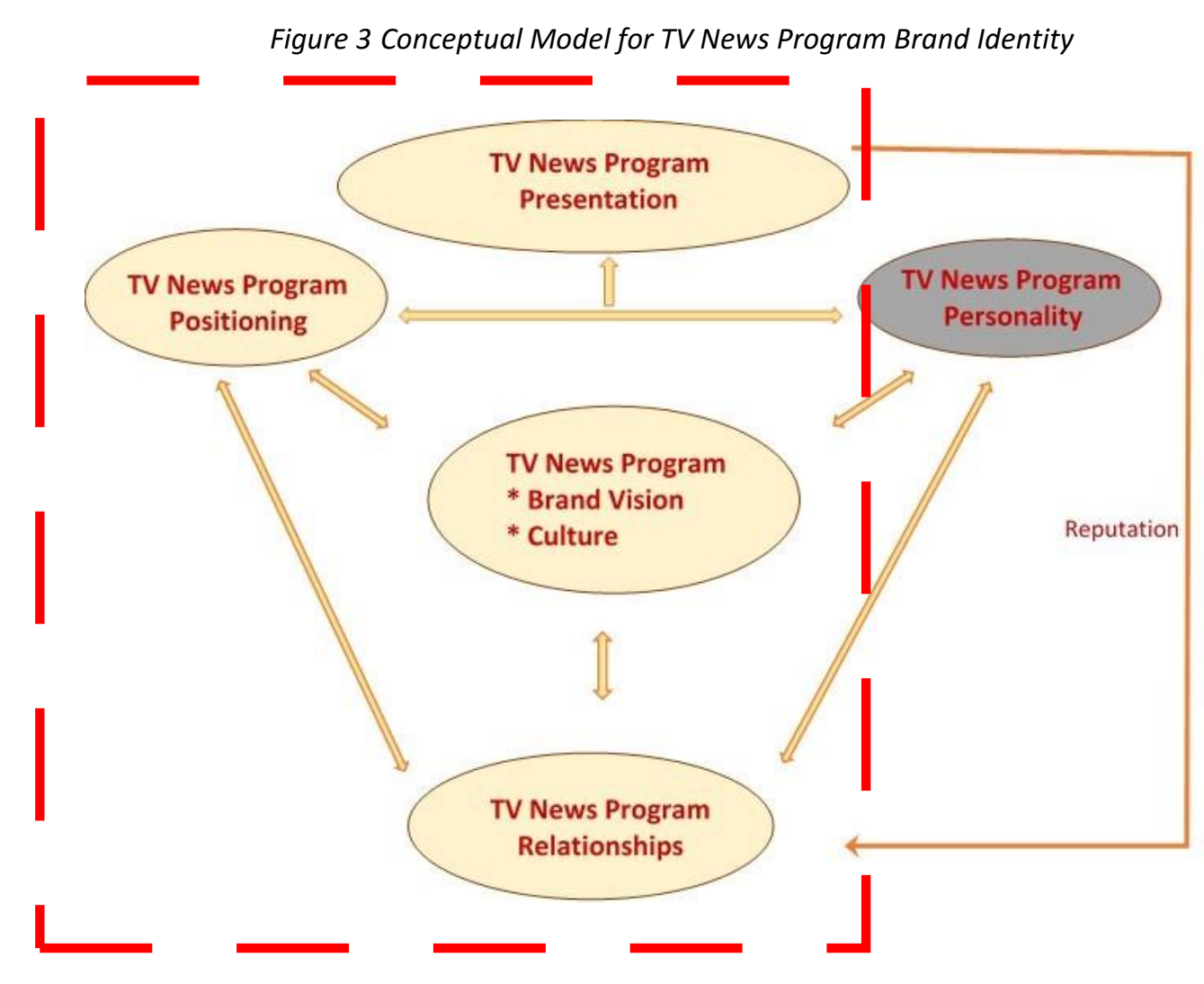

\section{Conclusion}

The systematic review of TV news program brand identity has been conducted. It is found that twelve papers (from sixteen papers) used the quantitative method, two papers used qualitative method and two papers applied mixed-method. Among the papers using quantitative method, the survey with questionnaires as research instrument is applied most.

There are five researches directly focusing on "Brand Personality". The other elements of "Brand Identity" (Brand vision, Brand culture, Brand positioning, Brand Relationship and Brand Presentation) are not stated explicitly in the reviewed papers. In order to fulfil and propose the conceptual framework of "Brand Identity" for TV news program, the author will further study by referring the research instruments and variables applied in the papers. 


\section{References}

Aaker, D.A. (1996). Building Strong Brands, New York: Free Press.

Aaker, D.A. and Joachimsthaler, E. (2000). Brand Leadership, New York: Free Press.

Azoulay, A. and Kapferer, J. N. (2003). "Do brand personality scales really measure brand personality?,” Brand Management, vol 11, pp. 143-155.

Bae, H. (2000). "Product differentiation in national TV newscasts: A comparison of the cable all-news networks and the broadcast networks," Journal of Broadcasting \& Electronic Media, vol. 44, pp. 62-77.

Chan-Olmsted, S. M. and Cha, J. (2007). "Branding television news in a multichannel environment: An exploratory study of network news brand personality," The International Journal of Media Management, vol. 9, pp. 135-150.

Chan-Olmsted, S. M. and Cha, J. (2008). "Exploring the antecedents and effects of brand images for television news: An application of brand personality construct in a multichannel news environment," The International Journal of Media Management, vol. 10, pp. 32-45.

Cheng, J. W. and Mitomo, H. (2017). Impact of Media Form on the Perceived Image of the Television News Media in the Age of Media Convergence. The $14^{\text {th }}$ International Telecommunications Society (ITS) Asia-Pacific Conference. Kyoto, Japan, pp. 24-27.

Coffey, A. J. and Cleary, J. (2011). "Promotional practices of cable news networks: A comparative analysis of new and traditional spaces," The International Journal of Media Management, vol. 13, pp. 161-176.

Cushion S. (2012). The Democratic Value of News: Why Public Service Media Matter, New York: Palgrave Macmillan.

Daniels, G. L., \& Loggins, G. M. (2010). "Data, doppler, or depth of knowledge: How do Television stations differentiate local weather," Atlantic Journal of Communication, vol. 18 , pp. 22-35.

De Chernatony, L. (1999). "Brand Management Through Narrowing the Gap Between Brand Identity and Brand Reputation,” Journal of Marketing Management, vol. 15, pp. 157-179.

Forster, K. (2011). "Key success factors of TV brand management: An international case study analysis," Journal of Media Business Studies, vol. 8, pp. 1-22.

Forster K. (2015). “An Audience-Centered Perspective on Media Brands: Theoretical Considerations, Empirical Results and 'White Spaces'," Handbook of Media Branding, pp. 281-293. 
Gutiérrez San Miguel, B. et al. (2010). "Analysing the development of TV news programmes: from information to dramatization," Revista Latina de Comunicacion Social, vol. 65, pp. 126-145.

Harcup, T. and O'neill, D. (2017). “What is News? News values revisited (again)," Journalism Studies, vol. 18, pp. 1470-1488.

Harris, F. and De Chernatony L. (2001). "Corporate branding and corporate brand performance ," European Journal of Marketing, vol. 35, pp. 441-456.

Hongprayoon, S. (2007). Tra koon rai kan kao to ra tat nai prat et thai por sor 2548 [Television News Genre of Thailand in 2005], Bangkok: Chulalongkorn University. (In Thai)

Jittanggoon, D. and Anantachart, S. (2010). "Brand personality in Thai news programs," Journal of Public Relations and Advertising, vol. 3, pp 158-177. (In Thai)

Kapferer, J. N. (1986). Beyond Positioning: retailers identity, ESOMAR seminar on Strategies for Retail Growth - Retailing Mix., pp. 167-175.

Kapferer, J. N. (2012). The New Strategic Brand Management: Advanced Insights and Strategic Thinking, London: KoganPage.

Kim, D. E. (2018). "My hero, your aggressor: Differences in perceptions of news media brand personality," International Journal of Communication, vol. 12, pp. 200-221.

Kitchen, P. J. and Schultz, D. E. (2003). "Integrated corporate and product brand communication (1)," Advances in Competitiveness Research, vol. 11, pp. 66-86.

Konecnik, M. and Go, F. (2008). "Tourism destination brand identity: The case of Slovenia," Journal of Brand Management, vol. 15, pp. 177-189.

Kumar, A. and Venkatesakumar, R. (2015). "Creating a business-media brand personality scale," International Journal of Business and Social Science, vol. 6, pp. 50-61.

McDowell, W. and Batten, A. (2005). Branding TV, New York: Focal Press.

Noppakhun, T. (1998). Professionalism of TV journalists, Bangkok: Chulalongkorn University. (In Thai)

Palczewski, M. (2009) "The term news - its concept and definition in Anglo-Saxon tradition. A review and classification attempt," Media Studies, Issue 35, pp. 1-15.

Roshco, B. (1975). Newsmaking. Chicago: The University of Chicago Press.

Santin, M. and Rubira, R. (2014). "Promotional practices in news programs: The case of Spanish public Television," International Journal of Communication, vol. 8, pp. 810-829.

Schultz, I. (2007). "The journalistic gut feeling Journalistic doxa, news habitus and orthodox news values," Journalism Practice, vol. 1, pp. 190-207.

Shaw, K. and Moungkaew C. (2016). "'Phuthorn 4G' identity of channel 7 news in digital TV age,” Panyapiwat Journal, vol. 8, pp. 216-228. (In Thai)

Siegert, G., Gerth, M. A. and Rademacher, P. (2011). "Brand identity-driven decision making by journalists and media managers - The MBAC model as a theoretical framework," The International Journal of Media Management, vol. 13, pp. 53-70. 
Singh, S. (2004). Building Television Programme Brands in the Digital Multi-channel Workdperspectives of the UK Television Professionals, UK: Bournemouth University.

Sjovaag, H. (2012). "Revenue and branding strategy in the Norwegian news market: The case of TV2 news channel," Nordicom Review, vol. 33, pp. 53-66.

Tuchman, G. (1978). Making news. New York: Free Press.

Upshaw, L. B. (1995). Building Brand Identity: A Strategy for Success in a Hostile Marketplace, New York: John Wiley.

Von Rimscha, M. B. (2015). "Branding Media Content: From Storytelling to Distribution," Handbook of Media Branding, pp. 157-167.

Woraphan, D. (1982). Ha sip pee khong to ra tat tai [50 years of Thai television], Bangkok:

Thammasart University Press. (In Thai) 